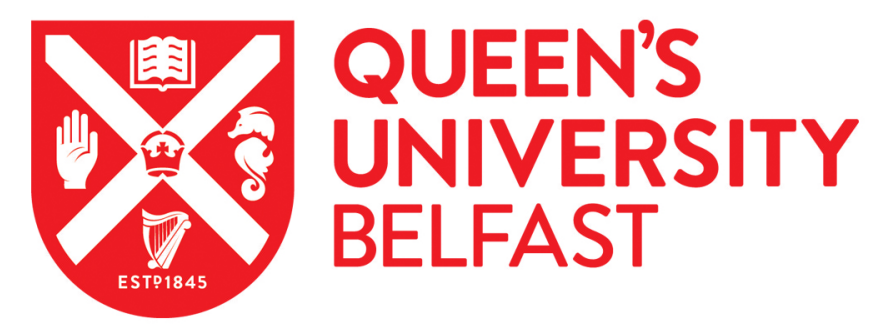

\title{
Modelling the Performance of Irish Credit Unions, 2002 to 2010
}

Glass, J. C., McKillop, D. G., \& Quinn, B. (2015). Modelling the Performance of Irish Credit Unions, 2002 to 2010. Financial Accountability \& Management, 30(4), 430-453. https://doi.org/10.1111/faam.12041

\author{
Published in: \\ Financial Accountability \& Management
}

\section{Document Version:}

Peer reviewed version

\section{Queen's University Belfast - Research Portal:}

Link to publication record in Queen's University Belfast Research Portal

\section{Publisher rights}

(C) 2014 John Wiley \& Sons Ltd

This is the peer reviewed version of the following article: Glass, J. C., McKillop, D. G. and Quinn, B. (2014), Modelling the Performance of Irish Credit Unions, 2002 to 2010. Financial Accountability \& Management, which has been published in final form at 10.1111/faam.12041. This article may be used for non-commercial purposes in accordance with Wiley Terms and Conditions for Self-Archivingjavascript:void(0);

\section{General rights}

Copyright for the publications made accessible via the Queen's University Belfast Research Portal is retained by the author(s) and / or other copyright owners and it is a condition of accessing these publications that users recognise and abide by the legal requirements associated with these rights.

Take down policy

The Research Portal is Queen's institutional repository that provides access to Queen's research output. Every effort has been made to ensure that content in the Research Portal does not infringe any person's rights, or applicable UK laws. If you discover content in the Research Portal that you believe breaches copyright or violates any law, please contact openaccess@qub.ac.uk. 


\section{Modelling the Performance of Irish Credit Unions, 2002 to 2010.}

J. Colin Glass, Ulster Business School, University of Ulster, Cromore Road, Coleraine, BT52 1SA, UK.

Corresponding Author: Donal G. McKillop, Queen's University Management School, Queen's University Belfast, Riddel Hall, 185 Stranmillis Road, Belfast, BT95EE, UK T: +44 (0)2890974852; F +44 (0) 2890974201; E-mail dg.mckillop@qub.ac.uk

Barry Quinn, Queen's University Management School, Queen's University Belfast, Riddel Hall, 185 Stranmillis Road, Belfast, BT95EE, UK 


\title{
Modelling the Performance of Irish Credit Unions, 2002 to 2010.
}

\begin{abstract}
This study undertakes a modeling based performance assessment of all Irish credit unions between 2002 and 2010, a particularly turbulent period in their history. The analysis explicitly addresses the current challenges faced by credit unions in that the modeling approach used rewards credit unions for reducing undesirable outputs (impaired loans and investments) as well as for increasing desirable outputs (loans, earning assets and members' funds) and decreasing inputs (labour expenditure, capital expenditure and fund expenses). The main findings are: credit unions are subject to increasing returns to scale; technical regression occurred in the years after 2007; there is significant scope for an improvement in efficiency through expansion of desirable outputs and contraction of undesirable outputs and inputs; and that larger credit unions, that are better capitalised and pay a higher dividend to members are more efficient than their smaller, less capitalised, and lower dividend paying counterparts.
\end{abstract}

Keywords: Credit unions, efficiency, impaired loans and investments 


\section{Modelling the Performance of Irish Credit Unions, 2002 to 2010.}

\section{Introduction}

Credit unions are not-for-profit, member-owned, voluntary, self-help, democratic, cooperative financial institutions that provide financial services to their members. In Ireland the credit union movement has one of the highest penetration levels in the world with approximately 65 percent of the population a member of a credit union. In 2010 there were 404 Irish credit unions with assets of $€ 14.1$ billion serving approximately 3 million members which equates to a population penetration level of 66 percent which suggests that credit unions are present in almost all communities in Ireland. Indeed, credit union penetration in Ireland is higher than in any other country in the world. The World Council of credit unions (WOCCU) estimated that in 2011 there were 51,013 credit unions in 100 countries, with 196.5 million members holding $\$ 1.56$ trillion in assets.

From the mid-1990s to 2007, Irish banks significantly expanded lending to the commercial and residential property sector. The collapse in prices and activity in both these markets post-2007 coupled with the downturn in general economic activity necessitated a major bailout for all Irish banks which now rely substantially on liquidity support from the ECB and the Irish Central Bank (McQuinn and Woods, 2012). The collapse of the banking sector, stagnating property markets and fiscal austerity has put extreme pressure on Irish households. Personal consumer expenditure fell by $1.1 \%$ in $2008,6.9 \%$ in $2009,0.8 \%$ in $2010,2.5 \%$ in 2011 and is projected to fall by $2.0 \%$ in 2012 while the unemployment

rate increased to $6.3 \%$ in $2008,11.8 \%$ in $2009,13.6 \%$ in $2010,14.4 \%$ in 2011 and is forecast to be $14.0 \%$ in 2012 (IBEC, January 2012). 
In that credit unions through legislation have not been permitted to engage in mortgage lending they have been protected from the worst excesses of the Irish financial crisis. Credit unions operate predominantly in the market for shorter term loans (less than 5 years) to Irish households. The banks cover this market and in addition the markets for long term loans to Irish households, loans to nonresidents, and loans to the non-financial Irish private sector (outstanding value of $€ 98$ billion in September 2011). That said, post 2007, adverse economic conditions have still impacted on Irish credit unions. In 2008 loans written off were $€ 41.85 \mathrm{~m}$, but rose to $€ 87.95 \mathrm{~m}$ in 2009 and $€ 107.44 \mathrm{~m}$ in 2010 (1.7\% of gross loans). It is also the case that the decline in the fortunes of Irish credit unions is not wholly related to economic factors. Other contributory factors include the business decisions of some credit unions and the deficiencies in the statutory regulatory framework, (Forsey, 2010).

Concern over the current position faced by credit unions as well as concerns about their future development was such that the Irish Government established a Commission in May 2011 to review the structural and regulatory landscape within which credit unions operate. The Commission's Report was published in March 2012 and identified a number of areas where reform is required ranging from the introduction of a new legislative framework to significant sectoral restructuring. With respect to the latter, the Commission argued that restructuring would involve moving from a situation where 408 credit unions operate and act independently, to one where there is consolidation through amalgamations and the development of close networks and shared services. They viewed restructuring as a way of addressing the current weaknesses in the sector as well as a business strategy for credit unions that want to achieve the scale necessary to move to a more efficient and sophisticated business model. Critical in the proposed plan is the identification of stronger credit unions which would anchor restructuring with other (weaker) participating credit unions. 
The current empirical study which investigates the relative performance of Irish credit unions over the period 2002 to 2010 provides evidence in support of sectoral restructuring. Furthermore, the analysis explicitly addresses the current challenges faced by credit unions in that the modelling approach used rewards credit unions for reducing undesirable outputs (impaired loans and investments) as well as for increasing desirable outputs and decreasing inputs. A pioneering application of this modelling to banking is provided in Park and Weber (2006), which uses the directional distance function approach of Chung et al (1997) for handling good and bad outputs. The Park and Weber (2006) study employed data envelopment analysis (DEA) to empirically model the production technology and to measure each bank's efficiency relative to the empirically-constructed best practice frontier. This type of nonparametric analysis can be readily extended by adding a parametric second stage which employs a regression technique to infer how various producer-specific factors influence the relative efficiency of the financial institutions involved. As an alternative to the preceding two-stage method for investigating efficiency determinants, the current study uses an application of the innovative Cuesta et al (2009) parametric approach to efficiency measurement.

The only previous investigation of Irish credit union performance is that of Glass et al. (2010) which is based on 2006 data and investigates performance determinants and the opportunity cost of regulatory compliance using a non-parametric methodology. A key finding of this analysis was that 68 percent of Irish credit unions do not incur an extra opportunity cost in meeting regulatory guidance on bad debt. The analysis also revealed that 93 percent of Irish credit unions operate at various levels of inefficiency and while best-practice and inefficient credit unions had many similar characteristics those identified as best-practice had much lower levels of bad debt and tended to be designated as industrial/associational credit unions. 
The present study yields a rich set of results. The analysis highlights that (i) Irish credit unions could improve productive performance by expanding desirable outputs while simultaneously contracting impaired loans and investments and inputs; (ii) that Irish credit unions are subject to increasing returns to scale; (iii) that larger credit unions, that are better capitalised and pay a higher dividend to members are more efficient than their smaller, less capitalised, and lower dividend paying counterparts; and (iv) that credit union efficiency levels have deteriorated significantly post 2007. These findings point to restructuring being necessary and additionally provide evidence that restructuring may be best achieved if it is anchored by those credit unions that pay better dividends, are larger and are better capitalised.

The remainder of the paper is structured as follows. In Section 2 we overview the efficiency literature on credit unions. The methodology is outlined in Section 3 and the data described in Section 4. Empirical results are presented and discussed in Section 5 with a summary and some concluding comments presented in Section 6.

\section{Efficiency Studies}

There is a large empirical literature on the measurement of cost structure and efficiency in the financial services industry (see Hughes and Mester, 2010). In contrasting the volume of work on banks with that on mutual financial services organizations, Worthington (2010, p.39-40) states:

"In the main, the substantive part of this research has focused on medium-to-large deposit-taking institutions .... [however], the need to understand issues of efficiency and productivity is no less pronounced in financial mutuals with the important role this information can provide in assessing the impact of regulation and yielding insights into the process of organisational and structural change characteristic of recent decades." 
Early studies in this area use either ratio analysis or simple production and cost functions to assess performance. For the US see for example Taylor (1972 and 1977), Wolken and Navratil (1980), Kohers and Mullis (1987 and 1988). For Australia, see Crapp (1983), Brown and O’Connor (1995) and more recently Esho (2000). For Canada, Murray and White (1983) and Kim (1986). For the UK, see McKillop et al. (1995) and for New Zealand Sibbald and McAlevey (2003). The general picture that emerges from these early studies is that credit union movements in most countries are characterised by increasing returns to scale. This provides a justification for growth strategies pursued by credit unions (either internally generated or via merger and acquisition) and for regulation permitting expansion of the common bond.

More recently credit union performance (efficiency) has been assessed employing frontier efficiency measurement based upon parametric and non-parametric techniques. The empirical measurement of economic efficiency centres on determining the extent of either allocative efficiency (the ability of an organization to use its inputs in optimal proportions, given their prices and the production technology) or technical efficiency (the ability to use resources in the most technologically efficient manner) or both in a given organization or industry.

For the US, Fried et al. (1993) evaluate performance using a Free Disposal Hull (FDH) analysis, which is a generalisation of DEA. The analysis highlights that there are a large number of best-practice credit unions with influences on efficiency traced to locational and institutional characteristics. Fried et al. (1996) use FDH to evaluate the performance of university-affiliated credit unions and compare their performance with that of other credit unions. They find support for the hypothesis that universityaffiliated credit unions, by virtue of the higher educational attainment of their membership, some of 
whom sit on the board of directors that oversees management, operate more efficiently than other credit unions. Frame and Coelli (2001) employ a stochastic cost frontier to investigate US corporate credit unions for the period 1992-1997. They find that $91 \%$ are cost efficient, with those credit unions investing a greater proportion of their assets in a centralised fund being most efficient. Glass and McKillop (2006), utilise a stochastic frontier approach to examine cost inefficiency under different environmental situations. The results suggest that: federal credit unions are more cost efficient than state credit unions and larger credit unions and multiple group credit unions are more cost efficient than their smaller, and single bond, counterparts. Wheelock and Wilson (2011) use a non-parametric locallinear estimator to estimate a cost relationship for credit unions and find evidence of increasing returns to scale over the period 1989-2006. They conclude that further deregulation which allows credit unions to expand their scale or scope of activities will lead to further increases in size and improvements in efficiency.

For Australia, Worthington (1998) and Esho (2001) utilise the parametric stochastic frontier approach while Brown et al. (1999) uses non-parametric data envelopment analysis (DEA). Worthington (1998) notes that large well capitalised credit unions with small branch networks are more efficient. Esho (2001) notes that there is little improvement in average efficiency over the period 1985 to 1993 . Brown et al. (1999) find no evidence that the average credit union moved closer to the efficient frontier

For the UK, McKillop et al. (2002) use DEA to obtain radial and non-radial efficiency measures while McKillop et al. (2005) use a stochastic frontier analysis to evaluate the relative performance for the period 1991 to 2001 . The results of both studies suggest that UK credit unions have considerable scope for efficiency gains. These studies also suggest that credit unions suffer from a considerable degree of scale inefficiency with in excess of 50 percent of scale inefficient credit unions subject to decreasing 
returns to scale. Glass et al. (2010) assess the efficiency of Irish credit unions using a two-stage approach. The analysis revealed that 93 percent of Irish credit unions operate at various levels of inefficiency, with this leaving seven percent of credit unions identified as best-practice. While bestpractice and inefficient credit unions had many similar characteristics it was clear that those identified as best-practice had much lower levels of bad debt and tended to be designated as industrial/associational credit unions. A further insight to emerge from the analysis was that 68 percent of Irish credit unions do not face a specific extra opportunity cost of complying with bad debt guidelines as dictated by the regulatory authorities.

Overall, there is less consistency in the observed findings for frontier based studies relative to the earlier production function and ratio based studies. Efficiency is influenced by an extensive range of factors, and the observed findings depend upon both the methodological approach utilised and the geographical area investigated. This is unsurprising given that the regulatory environment and maturity of credit unions differs between countries. Finally, while a small number of studies find a positive impact of size on efficiency, the remaining (majority) find little evidence of an empirical relation.

\section{Methodology}

This study examines the evolution of efficiency for Irish credit unions. In order to do this, we employ a translog enhanced hyperbolic distance function model to examine the relative performance of credit unions. Section 3.1 describes the enhanced hyperbolic distance function and efficiency, Section 3.2 details the translog version of the function, while Section 3.3 demonstrates the manner in which the function can be estimated within a stochastic frontier framework. 


\subsection{The enhanced hyperbolic distance function and efficiency}

Let us consider a financial institution productive process that transforms input vectors $x_{i}=\left(x_{1 i}, \ldots, x_{K i}\right) \in R_{+}^{K}$ into vectors of desirable outputs $y_{i}=\left(y_{1 i}, \ldots, y_{M i}\right) \in R_{+}^{M}$ and vectors of undesirable outputs $b_{i}=\left(b_{1 i}, \ldots, b_{R i}\right) \in R_{+}^{R}$, where $i=(1, \ldots, N)$ is the set of observed financial institution producers. The production technology is given by

$$
T=\{(x, y, b): x \text { can produce }(y, b)\}
$$

with this production possibility set assumed to be a compact set satisfying the axioms of production given in Färe and Primont (1995). Following Cuesta et al (2009), the production technology can also be represented by what they call an enhanced hyperbolic distance function $D_{E}(x, y, b)$. This represents the simultaneous maximum expansion of the desirable output vector and contractions of the undesirable output vector and input vector as defined by

$$
D_{E}(x, y, b)=\inf \{\theta>0:(x \theta, y / \theta, b \theta) \in T\}
$$

As (2) requires simultaneous equiproportionate expansion in $y$ and contractions in $b$ and $x$, it yields a hyperbolic path to the production frontier.

When weak disposability of outputs and inputs is assumed, $D_{E}(x, y, b)$ fully characterizes the technology and has a range $0<D_{E}(x, y, b) \leq 1$. The enhanced hyperbolic distance function (2) thus provides an efficiency measure. When the maximum equiproportionate expansion of $y$ and reductions in $b$ and $x$ (required to place a given observation (cooperative bank) on the boundary of $T$ ) is $D_{E}(x, y, b)=1$, the given financial institution is deemed to be an efficient producer located on the

production frontier. Contrariwise, if $D_{E}(x, y, b)<1$, the financial institution could improve its 
productive efficiency by expanding its production of $y$ and contracting its production of $b$ and usage of $x$ - hence it is deemed to be an inefficient producer.

As elucidated in Cuesta et al (2009), which extends Cuesta and Zofio (2005) by incorporating undesirable outputs, the enhanced hyperbolic distance function (2) satisfies the following properties: (i) it is almost homogeneous (ii) it is non-decreasing in desirable outputs, (iii) it is non-increasing in undesirable outputs and (iv) it is non-increasing in inputs.

\subsection{The translog specification of the enhanced hyperbolic distance function}

Property (i) above is particularly relevant to the empirical analysis as it can be imposed on a translog specification enabling the use of a parametric translog hyperbolic distance function for (technical) efficiency estimation. The model also allows for time-varying inefficiency (as explained further below). This is important as it is unlikely that (technical) inefficiency remains constant over our 20022010 time period. Note also that, in the empirical analysis over 2002-2010, the model will also allow for technical change (or shifts in the production frontier) as well as for the foregoing change in technical inefficiency. As indicated in Cuesta et al (2009), the translog enhanced hyperbolic distance function (or translog EHDF for short) can be estimated via a stochastic frontier framework to yield (technical) efficiency estimates for each credit union.

\subsection{Estimating the translog EHDF within a stochastic frontier framework}

In the stochastic frontier approach, a producer's distance from the production frontier is viewed as the combined outcome of technical inefficiency and random shocks outside the producer's control. To incorporate these two components, a composed error term $\varepsilon_{i t}$ is employed. Within this additive error 
term, the effects of random shocks on producer $i$ are captured by a two-sided, random-noise component $v_{i t}$, while a one-sided error component $u_{i t}$ is used to capture inefficiency.

The translog EHDF to be estimated is given by

$$
-\ln y_{M i t}=T L\left(x_{i t}^{*}, y_{i t}^{*}, b_{i t}^{*} ; \alpha, \beta, \gamma, \rho, \eta, \phi\right)+v_{i t}-u_{i t},
$$

where $-\ln y_{\text {Mit }}$ corresponds to the dependent variable and the $\varepsilon_{i t}=v_{i t}-u_{i t}$ is the composed error term. The $v_{i t}$ are assumed to be independently and identically distributed as $N\left(0, \sigma_{v}^{2}\right)$, independently distributed of the $u_{i t}$. The $u_{i t}$ are defined so as to embody the assumption that environmental conditions influence a credit union's technical inefficiency. Hence the technical inefficiency term is made an explicit function of a vector of producer-specific environmental variables $z_{i t}$. This is done by employing the Battese and Coelli (1995) maximum likelihood method which specifies that the $u_{i t}$ are independently (but not identically) distributed as truncations (at zero) of a general normal distribution of form

$$
\left|N\left(\mu_{i t}, \sigma_{u}^{2}\right)\right| \text { or }\left|N\left(\sum_{j=1}^{J} \delta_{j} z_{j i t}+e_{i t}, \sigma_{u}^{2}\right)\right|
$$

where $\delta_{j}$ are parameters to be estimated and $e_{i t}$ is a random variable which is independently distributed as a truncation of a normal distribution $N\left(\mu_{i t}, \sigma_{\mu}^{2}\right)$ such that $e_{i t} \geq-\delta_{j} z_{i t}$. This means that $\mu_{i t}$ distributed as a non-negative truncations of a normal distribution $N\left(\mu_{i t}, \sigma_{\mu}^{2}\right)$ in which $\mu_{i t}=\delta_{j} z_{i t}$ indicates that the expected value of $u_{i t}$ is influenced by different factors with a constant variance. In the empirical analysis, one of the elements of $z_{i t}$ is specified as a time trend to allow technical inefficiency to change with time.

The parameters of the model are estimated via maximum likelihood and, following Battese and Coelli (1988), the technical efficiency $\left(T E_{i t}\right)$ point estimators are obtained as $E\left[\exp \left(-u_{i t}\right) \mid \varepsilon_{i t}\right]$. In estimating 
the enhanced hyperbolic distance function model, the regressors $x_{k i t}^{*}=x_{k i t} y_{M i t}, y_{m i t}^{*}=y_{m i t} / y_{\text {Mit }}$ and $b_{r i t}^{*}=b_{r i t} y_{M i t}$ in equation (4) are considered to be exogenous.

\section{Data description}

The database upon which the analysis is based comes from a variety of sources. In each year the majority of the data (annual information on approximately 375 credit unions|) was provided by the Irish league of Credit Unions (ILCU). Data for credit unions affiliated to the Credit Union Development Association (CUDA), those that are independent of any trade body and those who had not filed returns to the ILCU were collected manually from the annual reports of the credit unions in question (25-30 credit unions per year). It should be noted that the data provided by member credit unions to the ILCU is unaudited. A nine year period is analysed from 2002 to 2010.

There are 404 credit unions registered in Ireland and this number has remained broadly stable over the course of the investigation period. Unfortunately a small number of credit unions failed to file returns in specific years and for others certain aspects of the data were either incomplete or inconsistent. In Table 1 we report summary statistics for the credit unions analysed in each of the years under consideration. It can be seen that between 2002 and 2009 our sample set consisted of a minimum of $374(90.1 \%)$ in 2002 and a maximum of $399(97.1 \%)$ in 2006. In 2010, the final year of the sample, we have only been able to obtain annual returns for 178 (44\%) of credit unions primarily because the supervisory function provided by the ILCU has in large part now been made redundant by the more overt monitoring of credit unions by the Central Bank. This has led to a number of credit unions not filing returns with the ILCU. Unfortunately the Central Banks does not provide data on individual credit unions to independent researchers. 
In the modeling of the productive process of credit unions there a number of ways in which inputs and outputs are specified - intermediation, production, value added, user-cost and asset approaches. The intermediation approach has tended to dominate empirical research (including the only other study on Irish credit unions, Glass et al. (2010)). Worthington (2010) suggests that the predominance of the intermediation approach is due to its adaptability which flows from the fact that categories of deposits, loans, financial investments and financial borrowings may be arbitrarily assigned to either inputs or outputs or excluded on the basis of a priori reasoning.

In this study the intermediation approach is utilised with a three input, three 'good' output and one 'bad' output process specified. The inputs are: (i) labour expenditure, $x_{1}$, (salaries, pension contributions, training and treasurer's honorarium), (ii) capital expenditure, $x_{2}$, (premises, equipment, depreciation, rent rates, light, heating, cleaning, repairs and renewals, equipment lease and maintenance expenditure) and (iii) fund expenses, $x_{3}$, (interest paid on deposits and dividends paid on members' shares). The 'good' outputs are: (i) members' funds, $y_{3}$, (members' shares and members' deposits), (ii) loans to members, $y_{1}$, and (iii) earning assets, $y_{2}$, (bank deposits, European Union (EU) government bonds, bank bonds and equity investments). The 'bad' output, $b_{1}$, is impaired assets which are impaired loans adjusted for investment losses. Mean and standard deviation values for the period 2002-2010 are presented for each of these variables in Table 1a.

The modeling process also provides insights into how certain producer-specific environmental variables influence credit union inefficiency. A number of variables proved important and summary statistics for these variables are detailed in Table $1 \mathrm{~b}$ and $1 \mathrm{c}$. The continuous variables in question are asset size; dividend ratio; return on assets (surplus/total assets); capital ratio and a liquidity ratio (see table 1c for details). Categorical variables are included to distinguish credit unions in terms of their 
common bond type, compliance with regulatory capital requirements and whether they have embraced web technology for product and service delivery. It should be noted that there is a relatively low level of web-based delivery of products and services. This can be traced to the failure in 2001 to introduce an integrated IT solution for Irish credit unions. This initiative cost $€ 100 \mathrm{~m}$ without any tangible end result. It then necessitated credit unions seeking IT solutions on an individual basis. However, such an approach is sub-optimal as even the largest credit unions do not have the financial resources to put in place systems which would enable them to compete effectively with, for example, the retail banks.

In the modeling of the productive process we also include a dummy variable to distinguish between credit unions with occupational/associational and community based common bonds. In an Irish context these two groups of credit unions are viewed as being subject to differences in their productive processes. Occupational credit unions draw their membership from a pre-designated employee group and by definition the membership is likely to be in either full- or part-time employment. Savings and loan repayments are invariably deducted straight from salary and in consequence these credit unions are subject to minimal bad debt problems. In contrast, community based credit unions draw their membership from a geographic area and this membership will be a mix of the employed, unemployed and retired. Linking savings and loan repayments directly to salary will not be an option for all members of community based credit unions. Furthermore, occupational credit unions in that they have a 'quasi-captive' membership will find it much easier to market and target products and services. This well-defined market could however also be viewed as an Achilles heel in that it implies that the membership mix of the credit union is undiversified and if the parent employer should face difficulties it will have a disproportionate effect on the credit union. From Table 1c we note that approximately $90 \%$ of credit unions have a community based common bond. 
From the information presented in Table 1a an insight can be obtained into two of the primary challenges now facing Irish credit unions - a decline in the loan book (with an associated rise in investments) and a rise in bad debts. From Table 1a we can calculate that the average loan to asset ratio has declined from $57.21 \%$ in 2002 to $39.07 \%$ (2010) and that investments as a percentage of assets have increased from $39.51 \%$ in 2002 to $47.36 \%$ in (2010). The guidance from the World Council of Credit Unions (WOCCU) suggests that an appropriate value for the loan to asset ratio should be somewhere between 70 and 80 percent. This emphasises that credit unions in Ireland are significantly 'under lent'.

Under lending has been an ongoing problem for the Irish movement since the late 1990s and has two main causes. First the loan product portfolio on offer from Irish credit unions is quite restricted and second competition in the financial market has intensified during at least the early part of the estimation period. There is however evidence that the financial crisis has led to the exit of some financial institutions from the Irish market (HBOS and PostBank) and significant retrenchment by others thus reducing competitive pressures (see Hanley and Rae, 2010). This respite is likely to be short-lived as commitments have been made by the Irish Government to the EU Competition Authority to undertake a set of measures "to restore competition in the Irish banking market by facilitating entry and expansion of competitors and enhancing the consumer protection in the financial sectors ". 1

From Table 1a we can also see that impaired assets have risen sharply since the start of the economic downturn. Between 2007 and 2008 impaired assets increased on average by 35\% from €495,000 to $€ 673,000$, increasing by a further $35 \%$ between 2008 and 2009 and by an additional 33\% between 2009 and 2010. These problems can be directly linked to the downturn in the Irish economy. In Ireland, personal consumer expenditure fell by $1.1 \%$ in $2008,6.9 \%$ in 2009 and $0.8 \%$ in 2010 while the

\footnotetext{
${ }^{1}$ http://ec.europa.eu/eu_law/state_aids/comp-2009/n546-09.pdf
} 
unemployment rate increased to $6.3 \%$ in $2008,11.8 \%$ in 2009 and $13.6 \%$ in 2010, (IBEC, January 2012).

\section{Empirical results}

The empirical results for the estimated model are presented in Table 2.

\subsection{Elasticities}

The parameter estimates for the $\alpha_{k}$ (input elasticities) indicate the magnitude of the respective input elasticities at the sample mean. Table 2 shows that all $\alpha_{k}$ have the expected negative sign and are significantly different from zero. The negative signs found are expected as any increase in the amount of inputs used (ceteris paribus) would mean a greater distance to the frontier. The $\alpha_{k}$ values reveal that while the labour expenses $\left(x_{1}\right)$ and capital expenses $\left(x_{2}\right)$ elasticities are very similar in size $\left(\alpha_{1}=-\right.$ 0.157 and $\alpha_{2}=-0.121$, respectively), the higher funds expenses $\left(x_{3}\right)$ elasticity value $\left(\alpha_{3}=-0.198\right)$ indicates the relatively more important role of this input in the credit union production process.

The estimated undesirable output parameter $\gamma_{1}$ (bad output elasticity) which is significantly different from zero, also has the expected negative sign in Table 2. When compared to the sizes of the input elasticity values, the impaired loans and investments elasticity value $\left(\gamma_{1}=-0.071\right)$ is lower indicating that, while still important, impaired loans and investments have relatively less importance in the distance function characterization.

The statistically significant $\beta_{m}$ estimates (good output elasticities), recorded in Table 2, all have the expected positive sign. This indicates that any increase in the amount of good outputs produced (ceteris paribus) would mean a smaller distance to the frontier. From Table 2, it can be seen that the relative sizes of the output elasticities show (as expected) loans $\left(y_{1}\right)$ to be considerably more important in the 
credit union production process than earning assets $\left(y_{2}\right)$ - the respective elasticity values being. $\beta_{1}=0.168$ and $\beta_{2}=0.048$. The finding that the earning assets elasticity is extremely low is a result of some importance in that it emphasizes that a further increase in an already 'unhealthily' high level of investments would result in only a marginal reduction in the distance to the frontier.

\subsection{Returns to scale}

Returns to scale measures for distance functions can be obtained in terms of the input and output elasticities. From Table 2 , it can be seen that the estimated value of the term is $\left[\left(-2 \Sigma_{k} \alpha_{k}\right)-\gamma_{1}\right]=$ 1.0202, thus suggesting increasing returns to scale. Computation of the relevant standard error $(0.0044)$ indicates that this finding of increasing returns to scale is significantly different from one (the constant returns to scale case) at the $5 \%$ level.

The finding of increasing returns to scale for Irish credit unions is consistent with what tends to be found for other credit union movements. Esho (2000), for Australian credit unions, found very pronounced increasing returns to scale. Murray and White (1983) and Kim (1986) both found 'slightly' increasing returns to scale for Canadian credit unions, while McKillop et al. (1995) and McKillop et al. (2002) found increasing and mainly non-decreasing returns to scale, respectively, for UK credit unions. Similar to the latter study, Sibbald and McAlevey (2002) found mainly non-decreasing returns to scale for credit unions in New Zealand, while both Glass and McKillop (2006) and Wheelock and Wilson (2011) found evidence of increasing returns to scale for US credit unions.

The finding of increasing returns to scale is also supportive of one of the policy recommendations emanating from the Irish Commission on Credit unions (2012) which advocates the establishment of a restructuring board to facilitate and incentivize credit union amalgamations "to provide the opportunity 
to stronger credit unions to develop a more sophisticated - and ultimately more sustainable - business model and provide a mechanism to sort through the financial stresses in the sector in an orderly way".

\subsection{Technical progress}

Time dummies were included to capture neutral technical change. Table 2 records that six of the time dummies coefficients $\left(\psi_{t}\right)$ are statistically different from zero. Four of these coefficients have a negative and significant sign, indicating technical progress or upward shifts in the production frontier while two have a positive and significant sign indicating technical regression or inward shifts in the frontier. It is noticeable that technical regression occurs in the period post 2007. Overall the values of these coefficients do suggest that aggregate technical regression of $2.62 \%$ was experienced over the 2002-2009 period (the coefficient estimate for 2010 is statistically insignificant so isn't considered in this calculation), thus giving an average annual rate of decline $0.33 \%$ over this period.

The technical regression of recent times may in part be linked to the uncertain and increasingly unstable environment that credit unions are now experiencing. Prior to 2008, cost to income ratios for credit unions trended around $47.0 \%$ since then they have steadily increased $62.2 \%$ (2008), 74.4\% (2009) and $83.3 \%$ (2010) with much of this increase driven by higher levels of provisioning. In such a deteriorating market environment credit unions are understandably reluctant to invest in infrastructural and technological enhancements and without such continued investment, technology becomes uncompetitive and technical regression may occur.

In the modeling of the productive process we also include a dummy variable with coefficient $\xi$, to distinguish between credit unions with occupational and community common bonds arguing that these two groups are subject to differences in their productive processes. The coefficient 
$\xi$ is negative $(-0.041)$ and significant at the $1 \%$ level indicating that more occupational rather than community credit unions raise credit union output. This reinforces the earlier observation that occupational credit unions, relative to community credit unions, have advantages in terms of a membership in full- or part-time employment and in the ease with which products and services can be marketed to members.

\subsection{Technical efficiency scores}

In proceeding to examine the technical efficiency scores, we first test the null hypothesis of no technical inefficiency. This test enabled us to reject the null hypothesis of no technical inefficiency effects in the Irish credit union production process. Since technical inefficiency does help to explain deviation from the production frontier, we can now examine how Irish credit unions could potentially improve their productive performance.

As the mean technical efficiency value for the estimated translog EHDF was 0.844 with a standard deviation of 0.137 . The mean technical efficiency value suggests that the Irish credit unions sector could improve its productive performance by expanding its desirable outputs by $18.48 \%(1 / 0.844=$ 1.1848), while simultaneously contracting its impaired loans and investments output and inputs by $16.6 \%(1-0.844=0.166)$. Note, in getting this empirical evaluation of productive performance, the translog EHDF model has the desirable property of crediting the credit unions for impaired loans and investments reduction as well as for desirable output expansion and input reduction. As Cuesta et al (2009) note, this enables a comprehensive approach to efficiency measurement which takes into account all outputs and input dimensions. This comment is particularly pertinent for Irish credit unions. Take as an example the manner in which the main trade association, the ILCU, oversees its member credit unions. On a quarterly basis credit unions are required to complete a report from which a range of compliance ratios are calculated. These ratios focus on all aspects of a credit union's business model 
including cost and financial structure, output mix, asset quality, and growth objectives. Guidance in the form of norms for the respective ratios are stipulated by the ILCU with the implicit recognition that adherence to for example cost based norms and loan loss targets will necessarily have implications for output mix and output levels.

In Figure 1 we present the kernel density estimate of the distribution of the technical efficiency scores. The estimated density indicates that the efficiency scores are clustered around 0.90. There is a pronounced left tail to the distribution with credit union technical efficiency being as low as 0.23. Overall approximately 31 percent of the efficiency values (1042 observations) are less than the mean technical efficiency score of 0.84 .

\subsection{Factors influencing the technical efficiency of credit unions}

In this section we discuss how the variables in the error term influence technical efficiency. Since the dependent variable is technical inefficiency, then a negative coefficient (the $\delta$ s in Table 2) means that as the variable goes up this reduces inefficiency (or raises efficiency). A number of interesting findings emerge.

As the asset size of a credit union increases efficiency improves up to an optimal level (this can be seen from the significant quadratic relationship that exists, with the coefficient of the square of asset size being positive and statistically significant). This may be indicative of the fact that up to a certain size there are scale and scope economies to be achieved. To explore the relationship between size and efficiency further we analysed the distribution of efficiency scores relative to asset size for credit unions in five size bands (less than $€ 20$ million, $€ 20$ million to less than $€ 40$ million, $€ 40$ million to less than $€ 60$ million, $€ 60$ million to less than $€ 100$ million and greater than $€ 100$ million). The key result to 
emerge was that credit unions with assets in excess of $€ 100 \mathrm{~m}$ are much more efficient on average than those in the other size categories.

Our analysis also highlighted that better capitalised credit unions are more efficient however set against that it was also the case that credit unions which held excessive levels of capital were found to be relatively inefficient. The distribution of the efficiency scores for credit unions that fell beneath regulatory capital guidelines over the period against those that met the capital requirements was also considered. The analysis demonstrated that those credit unions meeting capital requirements are on average more efficient that those that fail to meet the regulatory reserve guidelines. The Irish Commission on Credit unions (2012) found capital levels a problem for a number of credit unions. The Commission reported that there were 51 credit unions that as of December 2011 did not meet regulatory capital requirements. Furthermore the Prudential Capital Assessment Review undertaken by the Central Bank indicates that "the financial position of a significant number of credit unions will deteriorate markedly between now [March 2012] and 2013." Our analysis suggests that these credit unions are likely to have higher levels of technical inefficiency.

Occupational or associational credit unions are more efficient than their community based counterparts. The better performance of occupational/associational credit unions as earlier argued is influenced by the fact that the majority of their members are in salaried employment, whereas community credit unions may have a proportion of unemployed members. For certain occupational/associational credit unions there may also be some hidden 'in kind' advantages, for example many occupational/associational credit unions not only operate direct payroll deduction of loan repayments but also have a savings plan linked to salary. 
Credit unions that pay a higher dividend to their members are more efficient but credit unions with higher liquidity levels are less efficient. This latter result is not intuitively obvious. It occurs because credit unions in Ireland are under lent and in consequence many credit unions hold an excessive part of their asset base in highly liquid assets which although low risk will also be low return. The regulatory required liquidity ratio for credit unions is currently set at $20 \%$ however the average liquidity ratio in 2010 was $47.36 \%$ (see Table $1 b$ ).

A dummy variable is included to account for whether a credit union has a website. We do not distinguish between websites which are solely information based and those that enable financial transactions to be performed. Our findings suggest that credit unions with a website are more efficient than those that do not have a website. This 'customer facing' technological change brings with it additional delivery channels for a credit union's product offerings. Thus providing an increased flexibility to existing members coupled with lower per member processing costs.

Finally, we found deterioration in efficiency levels over the period 2002-2010 as earlier indicated this is to be expected given the significant deterioration in the Irish economy in recent years which has placed the business model of many credit unions under significant pressure. The Irish Commission on Credit unions (2012) highlights this when it states .. "the adverse economic conditions have resulted in a decline in credit union performance and have made it difficult for credit unions to replenish reserves through retained earnings, .... the declining fortunes of the Irish economy have not only put an additional brake on credit union development but arguably have contributed to regression in some credit unions." 


\subsection{Substitutability and complementariness relations in production}

Morrison-Paul et al (2000) have demonstrated how second-order cross terms can yield additional insights about interactions in the production process. For example, they show how $\alpha_{k l}$ reflects the extent of input substitutability or complementarity between inputs $x_{k}$ and $x_{l}$. They note that an increase in $x_{l}$ will both expand overall production and raise the marginal productivity of those inputs for which it is complementary more than those for which it is a substitute.

Table 3 shows that (in absolute terms) several of the values are not small in magnitude when compared to the corresponding first order $\left(\alpha_{k}\right)$ value. For example, Table 3 indicates that the labour expenses ( $x_{1}$ ) and capital expenses $\left(x_{2}\right)$ inputs are complementary in production, with an increase in one increasing the other's contribution to production. In contrast, Table 3 shows that relatively high substitutability exists between the funds expenses $\left(x_{3}\right)$ input and the capital expenses $\left(x_{2}\right)$ input and between the funds expenses input $\left(x_{3}\right)$ and the labour expenses $\left(x_{1}\right)$ input. The latter findings suggest, for example, that an increase in capital or labour expenses reduce the funds expenses input's contribution to production.

Similar cross terms, involving output and input interactions can be defined. In Table 3, a number of cross terms are not recorded (since the $\rho_{11}$ and $\rho_{22}$ parameter estimates are statistically insignificant in Table 2). The reported cross term values of -0.0137 and -0.0059 indicate that an increase in either the loans output $\left(y_{1}\right)$ or the earning assets output $\left(y_{2}\right)$ raises the funds expenses $\left(x_{3}\right)$ input's contribution to production with, as expected, the impact of $y_{1}$ on the productivity of $x_{3}$ more pronounced.

Table 3 records the computed values of the cross terms between the respective inputs and the bad output. The recorded values are $0.0541,0.0278$ and -0.0199 which suggests that an increase in impaired 24 
assets $b_{1}$ reduces the labour $\left(x_{1}\right)$ and capital expenses $\left(x_{2}\right)$ contribution to production and raises the funds expenses $\left(x_{3}\right)$ contribution to production. The latter result may follow from the fact that a rise in good loans $\left(y_{2}\right)$ raises $x_{3}$ 's productivity and the complementariness found between good loans $\left(y_{2}\right)$ and impaired loans and investments $\left(b_{1}\right)$, as reported below, means that as $y_{2}$ rises $b_{1}$ also rises yielding a negative value, as above.

Measures reflecting the interaction between desirable outputs can also be defined and are reported in Table 3. The computed values are 0.0085 and 0.0133 and indicate substitutability between the good loans and investments outputs in production, that is a rise in good loans $\left(y_{1}\right)$ output reduces the investments $\left(y_{2}\right)$ output's contribution to production and vice versa. As earlier noted there has been a sustained fall in loans as a proportion of assets and a commensurate rise in investments as a proportion of assets over the period under investigation. The Irish Commission on Credit unions (2012) is suggesting less restrictive business lending for larger credit unions and that credit unions be permitted to provide additional products /services subject to meeting specific requirements set by Central Bank. Our analysis would suggest that such a development would enable credit unions to beneficially rebalance their portfolios away from investments and towards loans.

Following Grosskopf et al (1995), Cuesta et al (2009) indicate how the translog EHDF can yield information about the relative difficulty or ease of substitutability between a desirable output $y_{m}$ and the undesirable output $b_{1}$. In interpreting such values, Cuesta et al (2009) note that the more negative (greater in absolute terms) values signal a higher opportunity cost of $y_{m}$ in terms of $b_{1}$ (relative complementariness) and vice versa. The estimated values are presented in Table 4. From Table 4, it can be seen that the highest relative complementariness $(-32.4878)$ is found between good loans and 
impaired loans and investments as expected. Table 4 also shows that the absolute values are all well beyond unity, suggesting that regulatory guidance to encourage impaired loans and investments to be kept to a minimum would have a substantial impact on credit union output and performance. This is precisely what prudential guidance, as implemented by the Central Bank, strives to secure by it requiring that credit unions minimize impaired loans and investments.

\section{Conclusions}

This study examines the relative performance of Irish credit unions over the period 2002 to 2010. The approach used rewards credit unions for reducing undesirable outputs (impaired loans and investments) as well as for increasing desirable outputs and decreasing inputs. Four important findings emerge which are supportive of policy measures now being advocated to bring forward significant legislative change for Irish credit unions including a new Credit Union Act (Credit Union Bill published September 2012) and structural reform (Credit Union Restructuring Board appointed August 2012). These changes are in part structural benchmarks for the EU-IMF support now being provided to Ireland.

First, it was estimated that on average Irish credit unions could improve productive performance by expanding desirable outputs by $18.5 \%$ while simultaneously contracting impaired loans and investments and inputs by $16.6 \%$, that Irish credit unions are subject to increasing returns to scale and that larger credit unions are more efficient than their smaller counterparts. The Irish Commission on Credit Unions (2012) had as one of its main policy recommendations the establishment of a Credit Union Restructuring Board to provide technical advice and capital funding to incentivise a major restructuring of the sector. This restructuring will involve the identification of anchor credit unions, those that are strongest within the sector, with weaker credit unions then merged into the anchor credit unions to create much larger entities. Our findings demonstrating significant technical efficiency 
differences, technical efficiency positively correlated with scale and a sector characterised by increasing returns to scale would suggest that the proposed restructuring will yield efficiency gains.

Second, our analysis found that larger credit unions that are better capitalised and pay a higher dividend to members are more efficient than their smaller, less capitalised, and lower dividend paying counterparts. This would suggest that the Credit Union Restructuring Board should build the restructuring process on credit unions which are large in terms of their asset base, are well capitalized and have continued to provide a good dividend to their members over our investigative period.

Third, we determined that there was a high degree of substitutability between loans and investments. A problem faced by Irish credit unions over the last decade is ongoing difficulties in the on-lending of funds and consequently accumulating an unhealthy level of investments. The Irish Commission on Credit Unions (2012) advocated that larger credit unions, that are capable of operating on a more sophisticated basis, should be allowed to offer a wider range of products and services and engage in a broader range of lending and investment activities. The Irish Credit Union Bill, published September 2012, provides for a more sophisticated and more permissive regulatory regime for larger credit unions. It details a three-tiered regulatory approach with 'tier three credit unions' (those with assets greater than $€ 100 \mathrm{~m})$ having additional regulatory requirements but also enhanced product and service flexibility. Our empirical analysis supports such developments by suggesting that the availability of new loan offerings will act as an important substitute for investments, thus pushing credit unions towards a more appropriate balance between lending and investment activities.

Fourth, over the investigative period technical regression is observed driven in the main by the post 2007 period. This finding emphasizes the extent to which recent adverse economic conditions have resulted in a decline in credit union performance. Challenging times are expected to continue, IBEC 27 
(2012) forecasts a decline in consumer expenditure and increases in unemployment in 2012 and 2013 while the Central Bank's Prudential Capital Assessment Review of credit unions anticipates a further deterioration in the financial position of a significant number of credit unions. This unpromising future for credit unions adds further support to the need for restructuring. 
Table 1a

Descriptive statistics

\begin{tabular}{|c|c|c|c|c|c|c|c|c|}
\hline \multirow[t]{2}{*}{ Outputs } & \multicolumn{2}{|c|}{ Members funds(000s) } & \multicolumn{2}{|c|}{ Loans(000s) } & \multicolumn{2}{|c|}{ Earning Assets(000s) } & \multicolumn{2}{|c|}{ Impaired Assets(000s) } \\
\hline & Mean & Standard Deviation & Mean & $\begin{array}{l}\text { Standard } \\
\text { Deviation }\end{array}$ & Mean & $\begin{array}{l}\text { Standard } \\
\text { Deviation }\end{array}$ & Mean & $\begin{array}{l}\text { Standard } \\
\text { Deviation }\end{array}$ \\
\hline 2002 & 16,897 & 21,638 & 11,176 & 14,969 & 7,870 & 11,038 & 239 & 381 \\
\hline 2003 & 19,494 & 25,033 & 11,979 & 16,059 & 9,922 & 13,850 & 303 & 453 \\
\hline 2004 & 22,376 & 28,809 & 12,966 & 17,284 & 12,094 & 16,821 & 359 & 546 \\
\hline 2005 & 24,946 & 31,060 & 13,579 & 16,603 & 14,374 & 20,032 & 404 & 609 \\
\hline 2006 & 25,965 & 32,165 & 13,745 & 16,717 & 15,413 & 21,354 & 441 & 682 \\
\hline 2007 & 24,332 & 31,084 & 13,468 & 18,071 & 14,203 & 19,619 & 495 & 779 \\
\hline 2008 & 24,458 & 30,839 & 14,319 & 18,842 & 13,509 & 18,986 & 673 & 980 \\
\hline 2009 & 25,197 & 31,725 & 14,040 & 18,764 & 14,986 & 19,992 & 914 & 1,283 \\
\hline 2010 & 23,241 & 21,941 & 11,951 & 12,079 & 15,023 & 15,709 & 1,218 & 1,397 \\
\hline Total & 23,005 & 29,049 & 13,101 & 16,982 & 12,944 & 18,085 & 519 & 852 \\
\hline \multirow[t]{2}{*}{ Inputs } & \multicolumn{2}{|c|}{ Labour expenses(000s) } & \multicolumn{2}{|c|}{ Capital expense(000s) } & \multicolumn{2}{|c|}{ Funds expenses(000s) } & \multicolumn{2}{|l|}{ Mean Ratio } \\
\hline & Mean & Standard Deviation & Mean & $\begin{array}{l}\text { Standard } \\
\text { Deviation }\end{array}$ & Mean & $\begin{array}{l}\text { Standard } \\
\text { Deviation }\end{array}$ & Loan to Assets & $\begin{array}{l}\text { Investments to } \\
\text { Assets }\end{array}$ \\
\hline 2002 & 157 & 172 & 47 & 46 & 380 & 665 & $57.21 \%$ & $39.51 \%$ \\
\hline 2003 & 174 & 195 & 51 & 52 & 417 & 733 & $52.97 \%$ & $42.33 \%$ \\
\hline 2004 & 206 & 244 & 55 & 55 & 348 & 506 & $49.18 \%$ & $43.55 \%$ \\
\hline 2005 & 216 & 233 & 61 & 65 & 398 & 605 & $46.07 \%$ & $44.35 \%$ \\
\hline 2006 & 228 & 248 & 65 & 68 & 429 & 707 & $42.66 \%$ & $43.38 \%$ \\
\hline 2007 & 233 & 249 & 64 & 66 & 407 & 752 & $41.44 \%$ & $40.57 \%$ \\
\hline 2008 & 257 & 285 & 70 & 70 & 508 & 880 & $43.61 \%$ & $37.69 \%$ \\
\hline 2009 & 279 & 307 & 74 & 77 & 409 & 777 & $43.05 \%$ & $43.37 \%$ \\
\hline 2010 & 261 & 250 & 70 & 64 & 256 & 407 & $39.07 \%$ & $47.36 \%$ \\
\hline Total & 221 & 248 & 61 & 64 & 403 & 699 & $46.54 \%$ & $42.16 \%$ \\
\hline
\end{tabular}

Note: All monetary variables are in euros and in 2002 real terms, having been deflated by the Consumer Price Index. 
Table 1b

Descriptive statistics

\begin{tabular}{|c|c|c|c|c|c|c|c|c|c|c|}
\hline \multirow{2}{*}{$\begin{array}{l}\text { Environmental } \\
\text { variables }\end{array}$} & \multicolumn{2}{|c|}{ Total Assets(000s) } & \multicolumn{2}{|c|}{ Dividend ratio } & \multicolumn{2}{|c|}{ Return on Assets } & \multicolumn{2}{|c|}{ Capital Ratio } & \multicolumn{2}{|c|}{ Pearl Liquidity ratio } \\
\hline & Mean & $\begin{array}{l}\text { Standard } \\
\text { Deviation }\end{array}$ & Mean & $\begin{array}{l}\text { Standard } \\
\text { Deviation }\end{array}$ & Mean & $\begin{array}{l}\text { Standard } \\
\text { Deviation }\end{array}$ & Mean & $\begin{array}{l}\text { Standard } \\
\text { Deviation }\end{array}$ & Mean & $\begin{array}{l}\text { Standard } \\
\text { Deviation }\end{array}$ \\
\hline 2002 & 19,549 & 25,322 & $2.10 \%$ & $1.06 \%$ & $0.80 \%$ & $1.49 \%$ & $9.97 \%$ & $2.97 \%$ & $39.51 \%$ & $14.30 \%$ \\
\hline 2003 & 22,872 & 29,645 & $2.00 \%$ & $1.03 \%$ & $0.75 \%$ & $1.59 \%$ & $10.23 \%$ & $3.01 \%$ & $42.33 \%$ & $13.75 \%$ \\
\hline 2004 & 26,872 & 34,737 & $1.72 \%$ & $1.79 \%$ & $0.75 \%$ & $1.53 \%$ & $10.28 \%$ & $3.48 \%$ & $43.55 \%$ & $13.19 \%$ \\
\hline 2005 & 30,769 & 38,237 & $1.53 \%$ & $0.87 \%$ & $0.73 \%$ & $1.52 \%$ & $10.41 \%$ & $2.99 \%$ & $44.35 \%$ & $12.29 \%$ \\
\hline 2006 & 33,681 & 41,565 & $1.51 \%$ & $0.80 \%$ & $2.07 \%$ & $1.93 \%$ & $12.48 \%$ & $3.15 \%$ & $43.38 \%$ & $11.61 \%$ \\
\hline 2007 & 33,469 & 42,683 & $1.49 \%$ & $0.93 \%$ & $2.40 \%$ & $2.06 \%$ & $13.83 \%$ & $3.15 \%$ & $40.57 \%$ & $11.76 \%$ \\
\hline 2008 & 33,942 & 42,659 & $1.81 \%$ & $0.98 \%$ & $2.71 \%$ & $2.31 \%$ & $13.63 \%$ & $3.20 \%$ & $37.69 \%$ & $12.26 \%$ \\
\hline 2009 & 33,319 & 41,629 & $1.40 \%$ & $0.95 \%$ & $2.36 \%$ & $2.39 \%$ & $12.74 \%$ & $3.24 \%$ & $43.37 \%$ & $12.25 \%$ \\
\hline 2010 & 30,959 & 29,301 & $0.87 \%$ & $0.73 \%$ & $1.42 \%$ & $1.73 \%$ & $12.45 \%$ & $2.94 \%$ & $47.36 \%$ & $11.75 \%$ \\
\hline Total & 29,444 & 37,509 & $1.65 \%$ & $1.11 \%$ & $1.56 \%$ & $2.04 \%$ & $11.74 \%$ & $3.48 \%$ & $42.16 \%$ & $12.87 \%$ \\
\hline
\end{tabular}

Table 1c

Categorical variables

\begin{tabular}{|c|c|c|c|c|c|c|c|c|c|}
\hline & \multicolumn{3}{|c|}{ Common Bond Type } & \multicolumn{3}{|c|}{ Regulatory reserve requirement } & \multicolumn{3}{|c|}{ Internet Technology Adoption } \\
\hline & community & occupational & Total & $\begin{array}{l}\text { Under } \\
\text { Capitalisted }\end{array}$ & $\begin{array}{l}\text { Appropriately } \\
\text { Capitalised }\end{array}$ & Total & No website & Live website & Total \\
\hline 2002 & 343 & 31 & 374 & 222 & 152 & 374 & 308 & 66 & 374 \\
\hline 2003 & 353 & 31 & 384 & 183 & 201 & 384 & 305 & 79 & 384 \\
\hline 2004 & 357 & 32 & 389 & 177 & 212 & 389 & 300 & 89 & 389 \\
\hline 2005 & 351 & 36 & 387 & 164 & 223 & 387 & 286 & 101 & 387 \\
\hline 2006 & 364 & 35 & 399 & 139 & 260 & 399 & 291 & 108 & 399 \\
\hline 2007 & 353 & 32 & 385 & 82 & 303 & 385 & 270 & 115 & 385 \\
\hline 2008 & 348 & 35 & 383 & 65 & 318 & 383 & 203 & 180 & 383 \\
\hline 2009 & 351 & 31 & 382 & 204 & 178 & 382 & 203 & 179 & 382 \\
\hline 2010 & 163 & 15 & 178 & 82 & 96 & 178 & 102 & 76 & 178 \\
\hline Total & 2983 & 278 & 3261 & 1318 & 1943 & 3261 & 2268 & 993 & 3261 \\
\hline
\end{tabular}

¡Capital Ratio $>8 \%$ in period $2002-2008$ or $>10 \%$ post 2008 . ${ }^{*}$ Capital ratio is below the regulatory reserve requirement. 
Table 2

Parameter estimates for the translog enhanced hyperbolic distance function

\begin{tabular}{|c|c|c|c|c|c|}
\hline Parameter & Estimate & $\begin{array}{c}\text { Standard } \\
\text { error }\end{array}$ & Parameter & Estimate & $\begin{array}{c}\text { Standard } \\
\text { error }\end{array}$ \\
\hline$\alpha_{0}$ & $0.500 * * *$ & 0.010 & $\phi_{11}$ & $0.026 * *$ & 0.012 \\
\hline$\alpha_{1}$ & $-0.157 * * *$ & 0.005 & $\phi_{21}$ & $0.041 * * *$ & 0.009 \\
\hline$\alpha_{2}$ & $-0.121 * * *$ & 0.009 & $\xi$ & $-0.041 * * *$ & 0.012 \\
\hline$\alpha_{3}$ & $-0.198 * * *$ & 0.003 & $\psi_{03}$ & -0.001 & 0.006 \\
\hline$\alpha_{11}$ & $-0.051 * * *$ & 0.003 & $\psi_{04}$ & $-0.020 * * *$ & 0.008 \\
\hline$\alpha_{12}$ & $0.009 * * *$ & 0.003 & $\psi_{05}$ & $-0.032 * * *$ & 0.008 \\
\hline$\alpha_{13}$ & $0.014 * * *$ & 0.001 & $\psi_{06}$ & $-0.044 * * *$ & 0.008 \\
\hline$\alpha_{22}$ & $-0.031 * * *$ & 0.005 & $\psi_{07}$ & $-0.024 * * *$ & 0.009 \\
\hline$\alpha_{23}$ & $0.013 * * *$ & 0.001 & $\psi_{08}$ & 0.0124 & 0.009 \\
\hline$\alpha_{33}$ & $-0.046 * * *$ & 0.001 & $\psi_{09}$ & $0.0262 * * *$ & 0.010 \\
\hline$\beta_{1}$ & $0.168 * * *$ & 0.019 & $\psi_{10}$ & 0.006 & 0.014 \\
\hline$\beta_{2}$ & $0.048 * * *$ & 0.017 & $\delta_{0}$ & 1.921 & 1.588 \\
\hline$\beta_{11}$ & $0.177 * * *$ & 0.036 & $\delta_{1}$ & $0.032 * * *$ & 0.004 \\
\hline$\beta_{12}$ & $0.034 * *$ & 0.017 & $\delta_{2}$ & $-2.782 * *$ & 1.184 \\
\hline$\beta_{22}$ & $0.048 * * *$ & 0.018 & $\delta_{3}$ & 0.321 & 0.328 \\
\hline$\gamma_{1}$ & $-0.071 * * *$ & 0.003 & $\delta_{4}$ & $-0.105^{* * *}$ & 0.043 \\
\hline$\gamma_{11}$ & $-0.043 * * *$ & 0.004 & $\delta_{5}$ & $-0.506 * * *$ & 0.183 \\
\hline$\rho_{11}$ & -0.015 & 0.015 & $\delta_{6}$ & $0.309 *$ & 0.181 \\
\hline$\rho_{12}$ & $-0.044 * * *$ & 0.017 & $\delta_{7}$ & $0.406 * * *$ & 0.070 \\
\hline$\rho_{13}$ & $0.018 * * *$ & 0.005 & $\delta_{8}$ & $-0.179 * * *$ & 0.073 \\
\hline$\rho_{21}$ & $-0.044 * * *$ & 0.011 & $\delta_{9}$ & $0.0525 * *$ & 0.026 \\
\hline$\rho_{22}$ & $-0.016^{*}$ & 0.010 & $\delta_{10}$ & $-0.291 * * *$ & 0.026 \\
\hline$\rho_{23}$ & $0.014 * * *$ & 0.004 & $\delta_{11}$ & $-0.029 *$ & 0.015 \\
\hline$\eta_{11}$ & $0.027 * * *$ & 0.003 & $\sigma^{2}$ & $0.037 * * *$ & 0.002 \\
\hline$\eta_{12}$ & $0.014 * * *$ & 0.003 & $\gamma$ & $0.9118 * * *$ & 0.067 \\
\hline \multirow[t]{2}{*}{$\eta_{13}$} & $0.010 * * *$ & 0.001 & $\operatorname{Ln} L$ & 2624.89 & \\
\hline & $\overline{T E}_{i t}$ & 0.844 & Standard Deviation $_{T E_{i t}}$ & 0.014 & \\
\hline
\end{tabular}

Note: $* 10 \%$ significance level $* * 5 \%$ significance level $* * * 1 \%$ significance level.

The $\delta^{\prime} s(j=1, \ldots, 9)$ are the coefficients of the $z$ variables influencing technical inefficiency, as given in $(21)$, with $\delta_{1}$ relating to a time trend; $\delta_{2}$ to dividend ratio; $\delta_{3}$ to return on assets; $\delta_{4}$ to regulatory reserve requirements dummy (appropriately capitalised 1 , undercapitalised 0$) ; \delta_{5}$ to capital ratio; $\delta_{6}$ to interaction term between capital ratio and regulatory reserve requirement dummy; $\delta_{7}$ to Pearl liquidity ratio; $\delta_{8}$ to $\log$ of total assets; $\delta_{9}$ to square of the log of total assets; $\delta_{10}$ to common bond type dummy (occupational 1 , community 0 ) and $\delta_{11}$ to internet technology adoption dummy (live website 1 , otherwise 0 ). Also, $\sigma^{2}=\sigma_{v}^{2}+\sigma_{u}^{2} ; \gamma=\sigma_{u}^{2} /\left(\sigma_{v}^{2}+\sigma_{u}^{2}\right)$; and $\overline{T E}_{i t}$ is the mean technical efficiency score. 
Table 3

Elasticities

\begin{tabular}{|c|c|c|c|c|}
\hline \multicolumn{5}{|c|}{ First order components } \\
\hline Loans & $\begin{array}{c}\text { Other Earning } \\
\text { Assets }\end{array}$ & Labour & Capital & Funds \\
\hline 0.1797 & 0.0307 & -0.1586 & -0.1205 & -0.1951 \\
\hline \multicolumn{2}{|c|}{ Second order cross components } & Funds \\
\hline \multicolumn{2}{|c|}{ Labour } & -0.0165 & 0.0333 \\
\hline Labour & 0.1138 & 0.0561 & 0.0319 \\
\hline Capital & -0.0169 & 0.0208 & -0.1143 \\
\hline Funds & 0.024 & 0.0278 & -0.0199 \\
\hline Loans & 0.0541 & -0.0093 & -0.0137 \\
\hline \multicolumn{2}{|c|}{} & 0.0176 & & -0.0059 \\
\hline Other Earning Assets & Loans & Other Earning & Assets & \\
\hline & -0.0069 & -0.0159 & \\
\hline Impaired Loans \& Investments & 0.0085 & & \\
\hline Other Earning Assets & & 0.0133 & \\
\hline Loans & & & \\
\hline
\end{tabular}

Note: From Table 2, the bad output elasticity at the sample mean is $\gamma_{1}=-0.071$. The gaps in the above table arise when the relevant parameter estimates are statistically insignificant, so that the corresponding interactive measures cannot be computed.

\section{Table 4}

Good $\left(y_{m}\right)$ and bad $\left(b_{1}\right)$ output substitutability

\begin{tabular}{|c|c|c|}
\hline & Loans & Other Earning Assets \\
\hline Impaired Loans \& Investments & -32.4878 & -27.7925 \\
\hline
\end{tabular}

Note: The above values are computed by observation. 
Figure 1: Distribution of Efficiency Scores

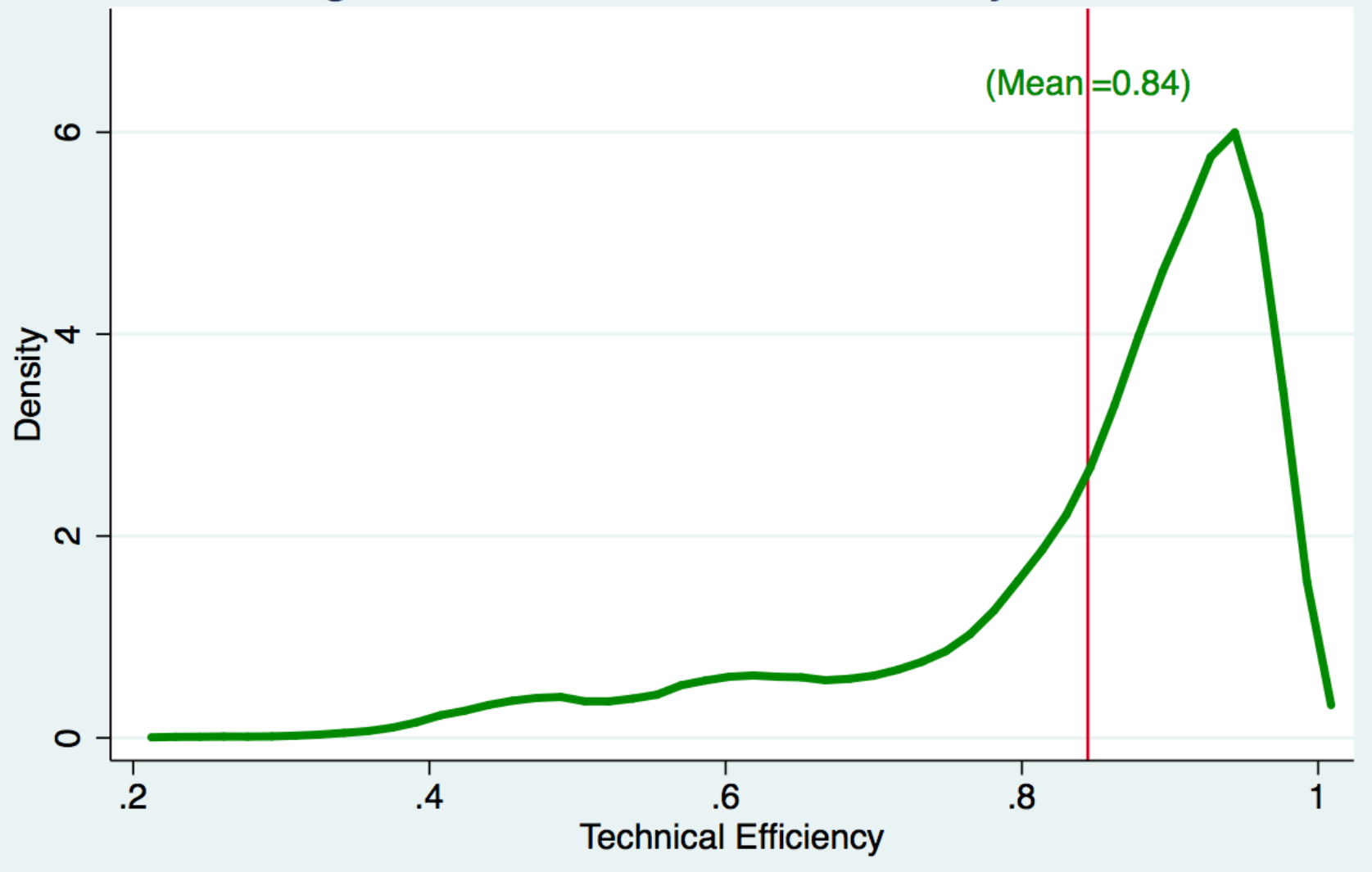




\section{References}

Battese, G.E., and Coelli, T.J., (1988), Prediction of firm-level technical efficiencies with a generalized frontier production function and panel data. Journal of Econometrics 38, 387-399.

Battese, G.E., and Coelli, T.J., (1995), A model for technical inefficiency effects in a stochastic frontier production function for panel data. Empirical Economics 20, 325-332.

Brown, R. and O' Connor, I. (1995), The measurement of economies of scale in Victorian credit unions, Australian Journal of Management, 20, 1-24.

Brown, R., Brown, R. and O'Connor, I. (1999), Efficiency, bond of association and exit patterns in credit unions: Australian evidence, Annals of Public and Cooperative Economics, 70: 5-23.

Crapp, H. (1983). Scale economies in the New South Wales credit union industry, Australian Journal of Management, 8: 35-48.

Cuesta, R.A., C.A.K Lovell and J.L. Zofío (2009), Environmental efficiency measurement with translog distance functions: A parametric approach. Ecological Economics 68, 2232-2242.

Cuesta, R.A., J.L. Zofío (2005), Hyperbolic efficiency and parametric distance functions: With application to Spanish savings banks. Journal of Productivity Analysis 24, 31-48.

Esho, N. (2000), Scale economies in credit unions: Accounting for subsidies is important, Journal of Financial Services Research 18, 29-43.

Esho, N. (2001). The determinants of cost efficiency in cooperative financial institutions: Australian evidence, Journal of Banking \& Finance, 25: 941-64.

Färe, R., and Primont, D., (1995). Multi-Output Production and Duality: Theory and Applications. Kluwer Academic Publishers, Dordrecht.

Forsey, L (2010), Using Waterford credit union as an exemplar of the larger Irish credit unions, what is the capacity and propensity of Irish credit unions to develop their current business model? Working Paper Series, (Finance Research Group), Waterford Institute of Technology, Ireland.

Frame, W.S. and Coelli, T. J. (2001). US Financial Services Consolidation: The case of corporate credit unions, Review of Industrial Organization, 18: 229-242.

Fried, H.O. Lovell, C.A.K. and Turner, J.A. (1996). An analysis of the performance of universityaffiliated credit unions, Computers and Operations Research, 23: 375-84.

Fried, H.O. Lovell, C.A.K. and Vanden Eekaut, P. (1993). Evaluating the performance of US credit unions, Journal of Banking \& Finance, 17: 251-65.

Glass, J.C., and McKillop, D.G., (2006). The impact of differing operating environments on US credit union performance, 1993-2001. Applied Financial Economics 16, 1285-1300. 
Glass, J.C., McKillop, D.G., and Rasaratnam, S., (2010). Irish credit unions: Investigating performance determinants and the opportunity cost of regulatory compliance. Journal of Banking and Finance 34, 1, $67-76$.

Grosskopf, S., Margaritis, D., and Valdmanis, V., (1995). Estimating output substitutability of hospital services: a distance function approach. European Journal of Operational Research 80, 575-580.

Hanley, C. and Rae, A., (2011). Stability and competition in Irish banking; Friends or Foes? Irish Competition Authority.

Hughes, J. and Mester, L. (2010). Efficiency in Banking: Theory, Practice, and Evidence, in Berger, A., Molyneux, P. And Wilson, J.O.S. (eds) Oxford Handbook of Banking. Oxford: Oxford University Press.

Hyndman, N.S., McKillop, D.G., Ferguson, C. and Wall, T., (2004). The financial accountability of Irish credit unions: An initial empirical study, Financial Accountability and Management, Vol. 20, No. 3 pp 281- 284.

Irish Business and Employers Confederation, (2012). Quarterly Economic Outlook, www.ibec.ie/economics, January 2012

Irish Commission on Credit Unions (2012). Report of the Commission on Credit Unions, March 2012. http://www.finance.gov.ie/viewdoc.asp?DocID=7210

Kim, H. Y. (1986). Economies of scale and economies of scope in multi-product financial institutions; further evidence from credit unions, Journal of Money, Credit and Banking 18, 220-6.

Kodde, D.A., and Palm F.C., (1986). Wald criteria for jointly testing equality and inequality restrictions. Econometrica, 54, 1243-1248.

Kohers, T. and Mullis, D. (1987). Credit union size as a cause for different operating characteristics, Mid-South Business Journal, 7: 14-18.

Kohers, T. and Mullis, D. (1988). An update on economies of scale in credit unions, Applied Economics, 20: 1653-1659.Kumbhakar, S.C., C.A.K Lovell (2000), Stochastic frontier analysis, Cambridge University Press, New York.

McKillop, D.G., Ferguson, C. and Nesbitt, D., (1995). Paired difference analysis of size economies in UK credit unions, Applied Economics 27, 529-537

McKillop, D.G., Glass, J.C. and Ferguson, C., (2002). Investigating the cost performance of UK credit unions using radial and non-radial efficiency measures. Journal of Banking and Finance 26, 1563-1591.

McKillop, D.G., Goth, P. and Hyndman, N., (2006). The structure, performance and governance of Irish credit unions, Gill and McMillan, Institute of Chartered Accountants in Ireland.

McQuinn, K., \& Woods, M. (2012). Modelling the corporate deposits of Irish financial institutions: 2009-2010. Research Technical Paper Central Bank of Ireland 2/RT/12. 
Morrison-Paul, C.J., Johnston, W.E. and Frengley, G.A.G., (2000). Efficiency in New Zealand sheep and beef farming: The impacts of regulatory reform. The Review of Economics and Statistics 82, 325337.

Murray, J.D., and White, R., (1983), Economies of scale and economies of scope in multi-product financial institutions: A study of British Columbia credit unions, Journal of Finance 38, 887-902

Park, K.H., and Weber W.L., (2006). A note on efficiency and productivity growth in the Korean banking industry, 1992-2002. Journal of Banking and Finance 30, 2371-2386.

Sibbald, A., McAlevey, C., (2002). An examination of key factors of influence in the development process of credit union industries, Annals of Public and Cooperative Economics Vol. 73, No. 2, pp. 399-428.

Taylor, R.A. (1972). Economies of scale in large credit unions, Applied Economics, 4: 33-40.

Taylor, R.A. (1977). Credit unions and economic efficiency, Rivista Internazionale di Scienzes Economicale e Commerciali, 24: 239-47.

Wheelock, D.C. and Wilson, P.W. (2011). Are credit unions too small? Review of Economics and Statistics, MIT Press, 93(4), pages 1343-1359

Wolken, J. and Navratil, R. (1980). Economies of scale in credit unions: Further evidence, Journal of Finance, 35: 769-77.

Worthington, A.C. (1998). The determinants of non-bank financial institution efficiency: A stochastic frontier approach, Applied Financial Economics, 8, 279-87.

Worthington, A.C., (2010). Frontier efficiency measurement in deposit-taking financial mutuals: A review of techniques, applications, and future research directions, Annals of Public and Cooperative Economics, 81(1), 39-75. 